\title{
Spiders (Araneae) of the selected synanthropic environments in Lublin City
}

\author{
Robert RozWALKA \\ * Department of Zoology, Maria Curie-Skłodowska University, Akademicka 19, 20-033 Lublin, Poland; \\ e-mail:rrozwalk@biotop.umcs.lublin.pl
}

\begin{abstract}
Material collected in the area of Lublin City in typical synanthropic environments were worked out. Collected species, depending on the level of attachment, were classified to 3 ecological groups: eusynanthropic species, hemisynanthropic and asynanthropic ones. The difference in frequency of occurring and numbers of many species were noticed, depending on the type of synanthropic environment. It was observed that outdoor walls of buildings were eagerly inhabited by species, which are associated with bark in natural conditions. This suggests that those species may supply the groups of synanthropic spiders in the future. Among 97 spiders recorded, the occurrence of Dipoena torva (TH.) and Leptorchestes berolinensis (C.L.K.) - very rare species in Poland and Central Europe was worth mentioning. It was also found, that Achaearanea tabulata LEVI is a stable and common element of Polish arachnofauna.
\end{abstract}

Key words: Araneae, synanthropic spider, Lublin City, Poland

\section{INTRODUCTION}

Spiders of typically synanthropic environments are rarely regarded as the subject of interest by arachnologists. In scientific papers they are treated marginally, especially while discussing the fauna of one area (e.g. Starega 1988, 2000, 2003). Huge differences refer also to the range of the term ,synanthropic environment”. In some cases (Dziabaszewski 1989, 1990), it covers spiders collected in different buildings as well as in their surroundings. In other cases „synanthropic environment" is restricted to varied kinds of buildings only (Dziabaszewski 1991a, Jankowski 1989). Such approach causes big troubles in interpreting and comparing the obtained results. The criteria of the division of arachnofauna into ecological groups are also a bit imprecise. Sacher (1983a-c) discussed synanthropic spiders occurring in Germany. Because of the level of synanthropy he separated spiders into three ecological groups: eusynanthropic species, hemisynanthropic species and xenosynanthropic species. Dziabaszewski in his papers (1987, 1990, 1991a, 1995), modelling himself upon the papers of Sacher (1983a-c), uses identical criteria though he names them a bit differently: synanthrophic species (= eusynanthropic species sensu Sacher 1983a), hemisynantropic species and asynanthropic species (= xenosynanthropic species sensu Sacher 1983a-c). Leaving out the matter of naming, the division itself into groups mentioned above, seems to be right, however, the selection of species for particular groups (especially hemisynanthropic species) is debatable in many cases.

A few papers entirely devoted to spiders occurring in the nearest neighbourhood of a human being (Dziabaszewski 1983, 1989, 1991a, b, 1995; Jankowski 1989) showed, that the fauna of such environments has its specific features. Complex account carried out on the examples of Poznań (Dziabaszewski 1989, 1991b) and Warszawa (Krzyżanowska et al. 1981) showed, that in the area of cities (in administrative limits) the number of recorded species may even reach the level of $30-40 \%$ of national fauna. Those results pointed out large adaptative abilities of spiders and considerable species diversity occurring in synanthropic environments (sensu lato). 
The papers that have been published so far suggested that there is a big regionalisation of synanthropic spiders and, at the same time, high homogeneity of the fauna inhabiting these environments (Dziabaszewski 1991a, b, 1995, Sacher 1989 a-c). Thus the effort of working out this problem on the example of the city of Lublin. The starting of researches seemed to be interesting because of expansion of some synanthropic species observed in Western Europe (Heinz et al. 2003, Klein et al. 1995, Moritz et al. 1988). The obtained results could give an answer to a question: have they reached Poland yet?

\section{MATERIAL AND METHODS}

The studies were conducted in the area of Lublin City $\left(22^{\circ} 33^{\prime} \mathrm{E}, 51^{\circ} 17^{\prime} \mathrm{N}\right)$ in the years 1999-2000 in five types of strictly synanthropic environments:

A - indoor spaces: apartments, staircases etc. (except for basements);

$\mathrm{B}$ - glasshouses;

$\mathrm{C}$ - outer building walls with western and northern exposition, often shaded with trees growing nearby (W-N);

$\mathrm{D}$ - outer building walls with eastern and southern exposition, non-shaded, strongly insolated (E-S);

E - concrete and asphalt squares, sidewalks and streets (,concrete deserts”).

The study areas were the buildings and squares situated in the campus of Maria CurieSkłodowska University in Lublin, between the streets: Akademicka, Głęboka Streets and Sowińskiego (sites A, C, D, E) as well as glasshouses of the Botanical Garden of Maria CurieSklodowska University in Lublin, Sławinkowska Street (B).

Because of the specificity of studied environments, spiders were collected from the noticed webs as well as from walls, crevices and wall bends, also from plants and walls of the glasshouses etc. Material was collected regularly, once a month, and the author tried to catch all of the observed spiders. In indoor species (A) as well as in the glasshouses (B) the samples were taken all year round, the remaining sites were penetrated in the period from March till November. Identified material was divided into three ecological groups:

- eusynanthropic species (Es) - species living exclusively in man-made conditions. They are not capable of surviving, undergoing the whole development cycle and overwintering outside;

- hemisynanthropic species (Hs) - species found mainly in synanthropic environment, although they occur often in natural conditions as well. They are capable of living, overwintering and breeding beyond synanthropic environment. Species known from Northern Poland only from synanthropic sites and, at the same time, frequently occurring in southern or southwestern part of the country in their natural biotopes were also included in this group.

- asynanthropic species (As) - spiders occurring in natural conditions, accidentally - in synanthropic environment, as well as spiders, for which the neighbourhood of a human being is neutral.

The division presented above is based on the divisions worked out by Sacher (1983a, b, c) and Dziabaszewski (1987, 1991a, 1995) with some development and refinement of classifying criteria for particular groups. The complete list of collected species with their classification to particular ecological groups is given in Table 1.

For particular kinds of synanthropic habitats the similarity of the species composition was calculated with Sørensen`s formula (QS):

$$
\mathrm{QS}=100 \frac{2 \mathrm{c}}{\mathrm{a}+\mathrm{b}}
$$

where: $c$ - number of species common for both assemblages, $a$ - number of species in the first assemblage, $b$ - number of species in the second assemblage. 
Nomenclature and family sequence was based on The World Spider Catalog (Platnick 2006) and the Checklist of Polish spiders (Starega 2004).

\section{RESULTS}

97 spider species were recorded in all of the studied types of synanthropic environments, out of which 7 were included to eusynanthropic species group, 16 to hemisynanthropic species group and the remaining ones - regarded as asynanthropic species (Table 1). Outer building walls with western and northern exposition, often shaded with trees growing nearby (C) were the richest type of synanthropic habitat. Among 675 collected specimens, 68 spider species were found. The fewest specimens - 39 only ( 22 species) were collected from concrete and asphalt squares (E) (Table 1). Indoor spaces (A) and glasshouses (B) have similar species compositions (A - 28 species; B - 31 species - Table 1). Insolated walls (D), despite similar number of species recorded from sites A and B (33 species), were characterized by high differences in qualitative and quantitative composition (Tables 1, $2 \& 3$ ).

Table 1. List of spiders collected in selected types of synanthropic environments in the area of Lublin City in the years 1999-2000; the species that have not been observed in Lublin Upland so far (Prószyński \& Staręga 1971, Staręga 1983, Rozwałka 1996, 2000) were marked with an asterisk (*); Ex - total number of individuals, A - indoor spaces; B - glasshouses; C - walls with western and northern exposition, often shade with trees growing nearby; D - walls with eastern and southern exposition, non-shaded, strongly insolated; E - concrete and asphalt squares, sidewalks, streets; EG - ecological group; As - asynanthropic species; Es - eusynanthropic species; Hs - hemisynanthropic species; ,?”controversial affinity.

\begin{tabular}{|c|c|c|c|c|c|c|c|c|}
\hline No. & Species & Ex & $\mathrm{A}$ & $\mathrm{B}$ & $\mathrm{C}$ & $\mathrm{D}$ & $\mathrm{E}$ & EG \\
\hline 1 & 2 & 3 & 4 & 5 & 6 & 7 & 8 & 9 \\
\hline & Pholcidae & & & & & & & \\
\hline 1 & Pholcus opilionoides (Schrank, 1781) & 14 & 7 & 4 & 3 & & & $\mathrm{Hs}$ \\
\hline 2 & P. phalangioides (Fuesslin, 1775) & 8 & 5 & 3 & & & & Es \\
\hline & Dysderidae & & & & & & & \\
\hline 3 & Harpactea rubicunda (C.L. Koch, 1839) & 1 & 1 & & & & & Hs \\
\hline & Mimetidae & & & & & & & \\
\hline 4 & Ero furcata (Villers, 1789) & 1 & & & 1 & & & As \\
\hline & Theridiidae & & & & & & & \\
\hline 5 & Achaearanea lunata (Clerck, 1758) & 35 & & 4 & 16 & 15 & & Hs \\
\hline 6 & A. tabulata Levi, 1980 & 207 & 24 & 48 & 111 & 22 & 2 & Hs \\
\hline 7 & A. tepidariorum (C.L. Koch, 1841) & 132 & 17 & 31 & 77 & 7 & & Es \\
\hline 8 & *Dipoena torva (Thorell, 1875) & 26 & & & 25 & 1 & & As \\
\hline 9 & Enoplognatha latimana Hippa et Oksala, 1982 & 2 & & & & 2 & & As \\
\hline 10 & E. ovata (Clerck, 1758$)$ & 6 & & 2 & 3 & 1 & & As \\
\hline 11 & E. thoracica (Hahn, 1833) & 1 & & & & & 1 & As \\
\hline 12 & Keijia tincta (Walckenaer, 1802) & 106 & & 8 & 53 & 45 & & As \\
\hline 13 & Neottiura bimaculata (Linnaeus, 1758) & 10 & 2 & 2 & 3 & 3 & & As \\
\hline 14 & Steatoda bipunctata (Linnaeus, 1758) & 55 & 11 & 14 & 21 & 9 & & Hs \\
\hline 15 & S. castanea (Clerck, 1758) & 141 & 39 & 38 & 64 & & & Es \\
\hline 16 & ${ }^{*} S$. grossa (C. L. Koch, 1838) & 35 & 19 & 8 & 8 & & & Es \\
\hline 17 & Theridion impressum L. Koch, 1881 & 1 & 1 & & & & & As \\
\hline 18 & *T. mystaceum L. Koch, 1870 & 33 & & & 29 & 4 & & Hs \\
\hline 19 & T. pinastri L. Koch, 1872 & 11 & & & 11 & & & As \\
\hline 20 & T. varians Hahn, 1833 & 102 & & 10 & 63 & 29 & & As \\
\hline & 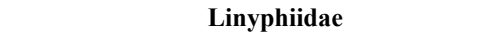 & & & & & & & \\
\hline 21 & Diplocephalus cristatus (Blackwall, 1833) & 3 & & & & & 3 & As \\
\hline 22 & D. picinus (Blackwall, 1841) & 1 & & & 1 & & & As \\
\hline 23 & Diplostyla concolor (Wider, 1834) & 4 & & & 4 & & & As \\
\hline 24 & Drapetisca socialis (Sundevall, 1832) & 6 & & 1 & 5 & & & As \\
\hline 25 & *Entelecara acuminata (Wider, 1834) & 20 & & & 20 & & & As \\
\hline 26 & Erigone atra Blackwall, 1833 & 7 & 2 & & 2 & 1 & 2 & As \\
\hline 27 & E. dentipalpis (Wider, 1834) & 3 & & & 1 & & 2 & As \\
\hline
\end{tabular}




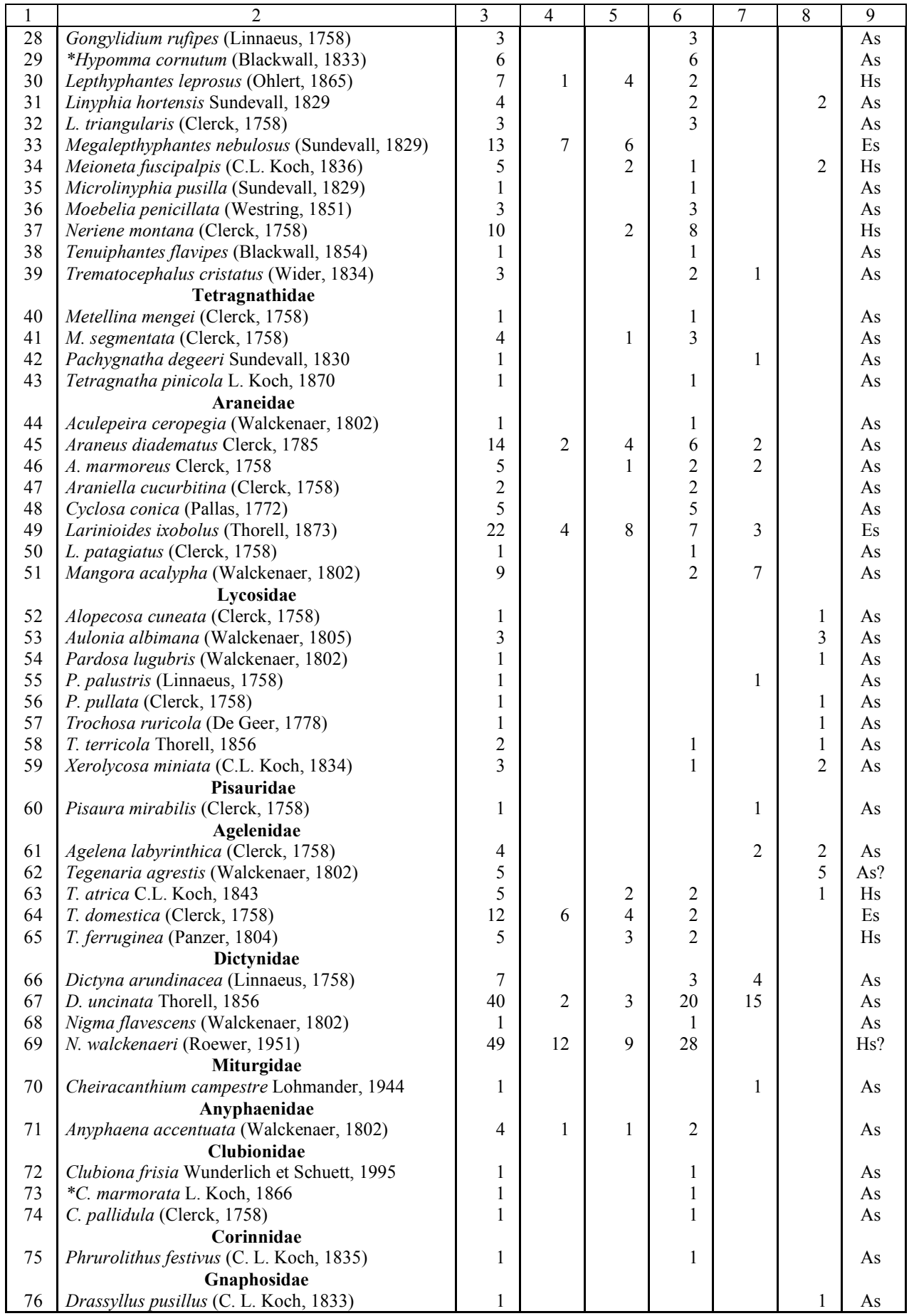




\begin{tabular}{|c|c|c|c|c|c|c|c|c|}
\hline 1 & 2 & 3 & 4 & 5 & 6 & 7 & 8 & 9 \\
\hline 77 & *Scotophaeus quadripunctatus (Linnaeus, 1758) & 2 & 1 & 1 & & \multirow{8}{*}{1} & & Hs \\
\hline & Philodromidae & & & & & & & \\
\hline 78 & Philodromus albidus Kulczynski, 1911 & 1 & & & 1 & & & As \\
\hline 79 & P. aureolus (Clerck, 1758) & 2 & 1 & & 1 & & & As \\
\hline 80 & P. cespitum (Walckenaer, 1802) & 3 & 1 & & 1 & & & As \\
\hline 81 & P. emarginatus (Schrank, 1803) & 1 & 1 & & & & & As \\
\hline 82 & *P. praedatus O.P.-Cambridge, 1871 & 2 & & & 2 & & & As \\
\hline & Thomisidae & & & & & & & \\
\hline 83 & Diaea dorsata (Fabricius, 1775) & 5 & 1 & 1 & 3 & \multirow{4}{*}{2} & & As \\
\hline 84 & Misumena vatia (Clerck, 1758) & 2 & & & & & & As \\
\hline 85 & Misumenops tricuspidatus (Fabricius, 1775) & 5 & 2 & & 3 & & & As \\
\hline 86 & Ozyptila praticola (C.L. Koch, 1837) & 2 & & & 1 & & 1 & As \\
\hline 87 & *Thomisus onustus Walckenaer, 1805 & 1 & & & & \multirow[t]{4}{*}{1} & & As \\
\hline 88 & Xysticus bifasciatus C.L. Koch, 1837 & 1 & & & & & 1 & As \\
\hline 89 & $X$. cristatus (Clerck, 1758) & 5 & 2 & & & & 3 & As \\
\hline & 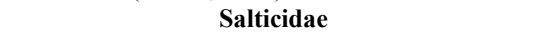 & & & & & & & \\
\hline 90 & Ballus chalybeius (Walckenaer, 1802) & 4 & \multirow{4}{*}{3} & \multirow{4}{*}{1} & 3 & \multirow{4}{*}{$\begin{array}{r}1 \\
29\end{array}$} & \multirow{8}{*}{1} & As \\
\hline 91 & *Leptorchestes berolinensis (C.L. Koch, 1846) & 33 & & & & & & As? \\
\hline 92 & Phlegra fasciata (Hahn, 1826) & 1 & & & & & & As \\
\hline 93 & Salticus cingulatus (Panzer, 1797) & 1 & & & 1 & & & As \\
\hline 94 & S. scenicus (Clerck, 1758) & 42 & \multirow[t]{4}{*}{3} & \multirow[t]{4}{*}{4} & 5 & 30 & & Hs \\
\hline 95 & S. zebraneus (C.L. Koch, 1837) & 2 & & & & 2 & & $\mathrm{Hs}$ \\
\hline 96 & *Sitticus pubescens (Fabricius, 1775) & 130 & & & 4 & 126 & & Hs \\
\hline 97 & Synageles venator (Lucas, 1836) & 3 & & & & 3 & & As \\
\hline & Total of species & 97 & 28 & 31 & 68 & 33 & 22 & \\
\hline & Total of individuals & 1496 & 178 & 230 & 675 & 374 & 39 & \\
\hline
\end{tabular}

Comparing percentage shares of particular ecological groups as well as their species composition in different types of synanthropic environments, some relationships have been noticed. The faunas of indoor spaces and glasshouses were very similar what was proved by quantitative and qualitative data (Tables $1,2 \& 3$ ) as well as by high convergence in composition and numbers of dominating species (Table 4). The specimens of synanthropic species (Es + Hs) constituted, in both separated synanthropic habitats, over $80 \%$ of collected spiders (Table 3). High similarity of fauna was reflected in the values of Sørensen's index (QS $=71.2 \%$ ). Comparing percentage shares of synanthropic forms to asynanthropic ones only (Es $+\mathrm{Hs})$, the similarity between the faunas of walls with W-N exposition $(\mathrm{C})(\mathrm{Es}+\mathrm{Hs})=57.8 \%)$ and E-S exposition (D) $(\mathrm{Es}+\mathrm{Hs})=58.3 \%$ can be noticed; however the analysis of species composition (Table 1) shows clear differences. Also a total result based only on the classification to ecological categories does not reflect the real differences which can be seen while comparing the total number of collected specimens in particular sites: $\mathrm{C}-675$ ex., $\mathrm{D}-$ 374 ex. as well as recorded species: $\mathrm{C}-68$ species, D -33 species. On the wall with W-N exposition, synanthropic species, especially from the genera Achaearanea and Steatoda, were numerous, while on insolated walls (S-E) they were in the minority (Table 1). The abovementioned differences are also apparent in dominance structure (Table 4) and in mean species similarity (Table 5). No eusynanthropic species were found on concrete and asphalt squares (E), hemisynanthropic ones were represented by 3 species (Table 1) and the remaining 19 belonged to asynanthropic species. That habitat had the highest species individuality (Tables $1 \& 5$ ).

The arrangement and composition of species recorded in indoor spaces (A), glasshouses (B) and walls with W-N exposition (C) showed high coincidence. In those types of synanthropic habitats, the following species reached the highest values of dominance index: Achaearanea tabulata, A. tepidariorum and Steatoda castanea (Table 4). Only Steatoda grossa, one of the dominants in apartments $(\mathrm{D}=10.7 \%)$, was a subdominant in glasshouses (3.5) and barely a recedent on the walls with W-N exposition (C) (Table 4). The composition of dominating species 
of strongly insolated walls with E-S exposition (D) was definitely different from the one described above. To eudominants belonged Sitticus pubescens $(\mathrm{D}=33.7 \%)$ and Keijia tincta $(12.0 \%)$, while dominants were represented by Salticus scenicus $(8.0 \%)$, Leptorchestes berolinensis $(7.8 \%)$ and Theridion varians $(7.8 \%)$. Among species dominating at sites A-C only Achaearanea tabulata had a significance share $(\mathrm{D}=5.9 \%)$, A. tepidariorum was a recedent $(\mathrm{D}=$ $1.9 \%$ ), while Steatoda castanea and S. grossa were absent (Tables 1 \& 4).

Table 2. Richness (S) and their percentage shares $(\mathrm{S} \%)$ of particular ecological groups in different types of synanthropic habitats of Lublin; symbols and the order of sites as in Table 1.

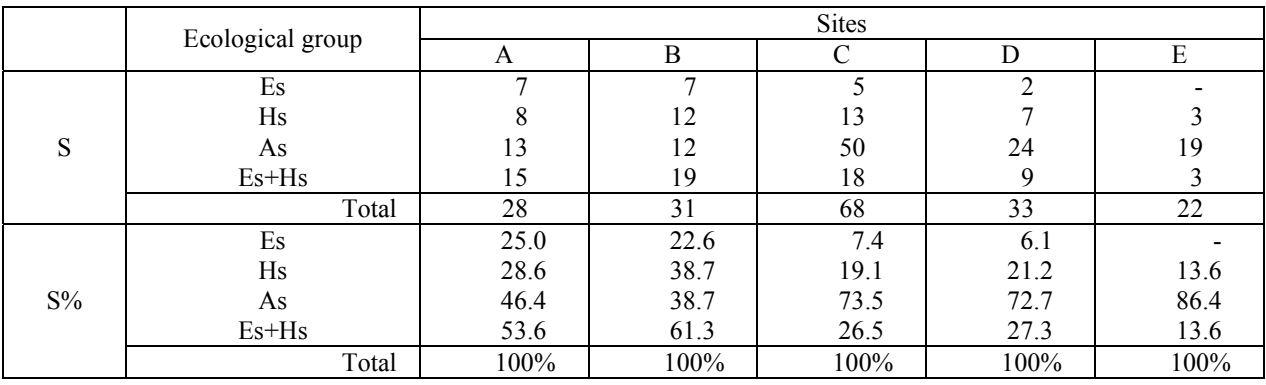

Table 3. Abundance $(\mathrm{N})$ and their percentage shares (N\%) from particular ecological groups in different types of synanthropic habitats of Lublin City. Symbols and the order of sites as in Table 1.

\begin{tabular}{|c|c|c|c|c|c|c|}
\hline & \multirow{2}{*}{ Ecological group } & \multicolumn{5}{|c|}{ Sites } \\
\hline & & A & B & C & D & E \\
\hline \multirow{5}{*}{$\mathrm{N}$} & Es & 97 & 98 & 158 & 10 & - \\
\hline & $\mathrm{Hs}$ & 60 & 97 & 232 & 208 & 5 \\
\hline & As & 21 & 35 & 285 & 156 & 34 \\
\hline & $\mathrm{Es}+\mathrm{Hs}$ & 157 & 195 & 390 & 218 & 5 \\
\hline & Total & 178 & 230 & 675 & 374 & 39 \\
\hline \multirow{5}{*}{$\mathrm{N} \%$} & Es & 54.5 & 42.6 & 23.4 & 2.7 & - \\
\hline & Hs & 33.7 & 42.2 & 34.4 & 55.6 & 12.8 \\
\hline & As & 11.8 & 15.2 & 42.2 & 41.7 & 87.2 \\
\hline & $\mathrm{Es}+\mathrm{Hs}$ & 88.2 & 84.8 & 57.8 & 58.3 & 12.8 \\
\hline & Total & $100 \%$ & $100 \%$ & $100 \%$ & $100 \%$ & $100 \%$ \\
\hline
\end{tabular}

The analysis of species similarity indices proved entirely the results obtained on the basis of the comparison between species composition and dominance structure. The faunas of glasshouses and indoor spaces were very similar $(\mathrm{QS}=71.2)$. The remaining types of synanthropic habitats, except for „concrete deserts” (E), had moderate values of similarity indices 39.3< QS $>$ 56.6. Spider assemblages inhabiting ,concrete deserts" temporarily were very distinct (Table 5).

The following spiders have not been found in Lublin during the researches: Psilochorus simoni, Amaurobius ferox, A. similis and Liocranum rutilans - they are synanthropic species known only from the cities of Western and Central Poland (Borowiec 1999, Dziabaszewki 1983, 1991a, 1995; Krzyżanowska et al. 1981). The remaining synanthropic species (Es + Hs) (except for Achaearanea tabulata which has not been published from Western Poland so far) were common in most cases. However, the numbers of particular species and dominance structure were quite different. The range of used terms of synanthropic environment (Dziabaszewski 1983, 1995, Jankowski 1989) as well as summation of data from different cities (Dziabaszewski 1990, 1991a) make difficult to compare the results obtained in Lublin. 
In Lublin the numerous occurrence of Achaearanea tabulata - rarely recorded from Poland - was found. It is a relatively new but very expansive newcomer in European fauna (Moritz et al. 1988). In Poland it has been recorded so far from Siedlce, Warszawa (Gromov 1997) and a few localities from Roztocze Upland (Rozwałka 2004). The results of the presented research showed that $A$. tabulata can be regarded as a common species and competes efficiently in synanthropic environments with another typical European eusynanthropic species A. tepidariorum.

Table 4. Dominating species in selected synanthropic habitats of Lublin City; eudominants > 10\%; dominants 5.1$10.0 \%$, subdominants $2.1-5.0 \%$, recedents $1.1-2.0 \%$, accessory species $<1.0 \%$ (marked with plus $(+$ ); because of small number of specimens the data from site $\mathrm{E}$ was not taken into consideration.

\begin{tabular}{|c|c|c|c|c|}
\hline \multirow{2}{*}{ Dominating species } & \multicolumn{4}{|c|}{ Sites } \\
\hline & $\mathrm{A}$ & $\mathrm{B}$ & $\mathrm{C}$ & $\mathrm{D}$ \\
\hline Pholcus opilionoides (SCHR.) & 3.9 & 1.7 & + & - \\
\hline P. phalangioides (FUESS.) & 2.8 & 1.3 & - & - \\
\hline Achaearanea lunata (CL.) & - & 1.7 & 2.4 & 4.0 \\
\hline A. tabulata LEVI & 13.5 & 20.9 & 16.4 & 5.9 \\
\hline A. tepidariorum (C.L.K.) & 9.6 & 13.5 & 11.4 & 1.9 \\
\hline Dipoena torva $($ Тн.) & - & - & 3.7 & - \\
\hline Keijia tincta (WALCK.) & - & 3.5 & 7.9 & 12.0 \\
\hline Steatoda bipunctata (L.) & 6.2 & 6.1 & 3.1 & 2.4 \\
\hline S. castanea (CL.) & 21.9 & $\mathbf{1 5 . 5}$ & 9.5 & - \\
\hline S. grossa (C.L.K.) & 10.7 & 3.5 & 1.2 & - \\
\hline Theridion mystaceum (L.K.) & - & - & 4.3 & 1.1 \\
\hline T. varians HAHN & - & 4.3 & 9.3 & 7.8 \\
\hline Entelecara acuminata (WID.) & - & - & 3.0 & - \\
\hline Megalepthyphantes nebulosus (SUND.) & 3.9 & 2.6 & - & - \\
\hline Larinioides ixobolus (Тн.) & 2.2 & 3.5 & + & + \\
\hline Tegenaria domestica (CL.) & 3.4 & 1.7 & + & - \\
\hline Dictyna uncinata $\mathrm{TH}$. & + & 1.3 & 3.0 & 4.0 \\
\hline Nigma walckenaeri (ROEWER) & 6.7 & 3.9 & 4.1 & - \\
\hline Leptorchestes berolinensis (C.L.K.) & 1.7 & + & - & 7.8 \\
\hline Salticus scenicus (CL.) & 1.7 & 1.7 & + & 8.0 \\
\hline Sitticus pubescens (FABR.) & - & - & + & 33.7 \\
\hline
\end{tabular}

On the basis of this research no clear replacement of Pholcus opilionoides by $P$. phalangioides was found in contrary to fact mentioned by Dziabaszewski (1995). These species have quite unlike environmental preferences. $P$. opilionoides inhabits relatively dry places (e.g. apartments, upper parts of buildings, also humid, but with a low temperature chilly basements). P. phalangioides prefers a bit humid but quite warm spaces (bathrooms, lower parts of buildings, warmer basements).

Table 5. Species composition similarity of spiders of selected types of synanthropic environment in Lublin according to Sørensen`s index (QS).

\begin{tabular}{|c|c|c|c|c|c|}
\hline A & 100 & & & & \\
\hline B & 71.2 & 100 & & & \\
\hline $\mathrm{C}$ & 43.8 & 56.6 & 100 & & \\
\hline D & 39.3 & 46.9 & 45.5 & 100 & \\
\hline \multirow[t]{2}{*}{$E$} & 16.0 & 15.1 & 22.2 & 14.6 & 100 \\
\hline & A & B & $\mathrm{C}$ & $\mathrm{D}$ & $\mathrm{E}$ \\
\hline
\end{tabular}

Worth mentioning is the fact that the walls of buildings were relatively numerously inhabited by species which inhabit bark in natural conditions (Dipoena torva, Keijia tincta, 
Theridion mystaceum, T. varians, Drapetisca socialis, Entelecara acuminata, Moebelia penicillata, D. uncinata, Anyphaena accentuata, Clubiona marmorata, Philodromus spp. Ballus chalybeius, Leptorchestes berolinensis). It shows high adaptative abilities of these species as well as it may be treated as the initial stage of synanthropisation. Especially such species as Keijia tincta. Theridion varians and Dictyna uncinata seem to be candidates for supplying the group of hemisynanthropic species in the near future. The similar situation refers to Leptorchestes berolinensis, which in natural conditions inhabits rock walls. In Polish conditions this species should be included to hemisynanthropic species rather because of more frequent observations of this spider on building walls than in natural environment.

\section{NOTES ON SOME SPECIES}

\section{Achaearanea tabulata Levi}

Species described relatively recently from synanthropic environments of Northern America (Levi 1980). In Europe it was recorded for the first time in 1988 (Moritz et al. 1988). In a short period of time it also appeared in most European countries (Dimitrov 1994, Knoflach 1991). In the area of Poland it was first mentioned by Gromov (1997). Lately it has been found in Poznań (Dziabaszewski 2002) and Roztocze Upland (Rozwałka 2004). Nowadays, on the example of Lublin, it is more numerous than A. tepidariorum in synanthropic environments. It occupies almost the same ecological niche as A. tepidariorum but it shows higher adaptive abilities. Thus it is observed in different types of natural biotopes often (Rozwałka 2004, and unpublished data). Quite high frequency of this species on strongly insolated walls in Lublin as well as high numbers in central parks of Lublin where this species effectively competes with $A$. lunata constitute a proof of its high adaptive abilities.

\section{Achaearanea tepidariorum (C.L. Koch)}

This species has been regarded as a typical synanthropic representative of the genera Achaearanea in Europe so far. The obtained numbers of A. tabulata and A. tepidariorum in different habitats as well as observations allow to suppose that, nowadays, $A$. tepidariorum is partially displaced by more expansive $A$. tabulata.

\section{Dipoena torva (Th.)}

A very rare European species, in Poland known only from three localites (Czajka 1966, Staręga 1983, Sterzyńska \& Ślepowroński 1994). It is caught on shaded walls of buildings, in nature it inhabits trunks and branches of trees (Simon 1997). The number of this species was always higher after strong winds that shook spiders off from treetops to building walls. After 2000 , when the majority of the trees adjoining walls were removed, single specimens of spiders were recorded only (author's unpublished data). In Lublin this species was numerously observed in central parks too (author's unpublished materials).

\section{Theridion mystaceum L. Koch}

Starega (1988) gave out that this species inhabits hollows and bark, sporadically - building walls. In Lublin it was observed numerously on building walls (mainly shaded) as well as on bark in central parks (author's unpublished data). The record of rock living T. melanurum HAHN from buildings of Roztocze given by Dziabaszewski (1990) and the lack of $T$. mystaceum at the same time should be regarded as a misidentification.

\section{Tegenaria agrestis (Walck.)}

All of the specimens of this species were collected in autumn (September-October) in the evening and night hours on concrete or asphalt squares of Lublin. Spiders circled in places illuminated with street lamps hunting for insects attracted to light. A species found mostly in 
cities (Krzyżanowska et al. 1981), or in habitats strongly inhabited by human activity: e.g. mine waste dumps (Staręga 1996), areas degraded by industrial pollution (Puszkar 1981, Staręga 1984). It was introduced to Northern America where acclimatized itself perfectly and now it is regarded as one of the most poisonous spider, so called „hobo spider" (Baird \& Akre 1993, Baird \& Stoltz 2002). Dziabaszewski (1995) treated this species as a synanthropic one.

\section{Nigma walckenaeri (Roewer)}

Sacher (1983a) includes this species to eusynanthropic ones. Dziabaszewski (1990) had mentioned it among hemisynanthropic species, however, in the next papers - among asynanthropic species. In Lublin, in contrary to Poznań (Dziabaszewski 1995) and Opalenica (Jankowski 1989) where single specimens were found, very numerous. Observations on phenology and environments of occurring given by Rozwałka (2004) while discussing the spiders of Roztocze showed that this species should be included in the group of synanthropic species.

\section{Thomisus onustus Walck.}

Quite rare in Poland, xero- and heliophilous species, found on flowers and tops of shoots of herbaceous plants (Prószyński \& Staręga 1971). The individual caught on the wall might have arrived from the wall adjacent to buildings on a dry slope.

\section{Leptorchestes berolinensis (C.L. Koch)}

A south and central European species, very rare in Poland (Prószyński \& Staręga 1971, Staręga 1983, Żabka 1997). It occurred on well-insolated walls only, from which sometimes it passed to indoor spaces. It was observed, that ants are not the only food of this species. Young individuals of Sitticus pubescens and Salticus scenicus fell its prey as well.

\section{Sitticus pubescens (Fabr.)}

In Lublin this species was the definite dominant $(\mathrm{D}=33.7 \%)$ on well-insolated walls, sporadically it occurred in shaded places (Table 1). In Poznań and other cities of western Poland this species is not numerous or absent (Dziabaszewski 1983, 1987, 1991a, 1995; Jankowski 1983). Dziabaszewski (1990) mentioned Sitticus terebratus (Cl.) from synanthropic environments of Roztocze in hemisynanthropic category. Almost for sure it was a mistake, the author misidentified the individuals of $S$. pubescens, which was not mentioned in his paper.

\section{Synageles venator (Lucas)}

A hygrophilous spider inhabiting reeds on shores of water bodies (Żabka 1997). Except for three mentioned individuals from the years 1999-2000, in the following years next individuals were observed (only males or subadult males $2001-3$ individuals, $2003-2,2004-1$ author's unpublished materials). This data proved the aeronautic abilities of this species because the nearest suitable habitats were situated 3 to $8 \mathrm{~km}$ from the study area.

\section{DISCUSSION}

In the light of literature data (for example Dziabaszewski 1990, 1991a, b, Povolny 1963, Sacher 1983a-c, Schmidt et Krause 1996, Valesova-Zdarkova 1966, Vanuytven 1987) which are rather poor and refer to different ranges of determined species and synanthropic environments, the interpretation of the results is not univocal. The number of species recorded in indoor spaces (28) is lower than one given by Dziabaszewski (1995, Table 1) from Poznań (35 species) on the basis of his researches conducted over 26 years. Definitely, the richest fauna of spiders was found in glasshouses - 31 species, while Dziabaszewski (1995, Table 5) in Poznań, also on the bases of his researches conducted over 26 years, revealed in the same type of environment 9 species only. However, the remaining papers of Dziabaszewski (1983, 
1995) as well as of Jankowski (1989) give total data while discussing the spiders of synanthropic habitats. The lists of spiders included in these papers match the sum of results form sites A, C, D from this paper. The way things stay, 85 spider species recorded from Lublin must be treated as a definitely higher result than 56 species for Poznań (Dziabaszewski 1995, Table 6) and 32 species given for Opalenica and Grodzisko Wielkopolskie (Jankowski 1989). In other papers Dziabaszewski $(1990,1991$ a) discusses the total results obtained for several (several dozen?) of towns. Against this fact, the recorded fauna of Lublin is also richer than the synanthropic fauna of Roztocze Upland (Dziabaszewski 1990) or in the former Elblag Region - 32 species (Dziabaszewski 1991a).

Dziabaszewski (1991a) used for the characteristic of spider assemblages of synanthropic environments the analysis of percentage share of particular ecological groups Es:Hs:A. On the example of Malbork and other towns of the vicinity of Elblag he obtained the share of synanthropic forms (Es+Hs) within bounds of $72-75 \%$. Presented results show that this parameter has a small importance for the analysis of a synanthropic fauna. A percentage share of a definite group to the whole assemblage provides no information about its abundance. Synanthropic species constitute a relatively small percentage of species in the whole fauna but they reach high numbers (Table 1). The percentage share of specimens from particular ecological groups (Table 3 ) is definitely a better index characterising a fauna of synanthropic environment.

\section{CONCLUSIONS}

- Conducted researches proved that spider fauna occurring in synanthropic environments of Lublin City was considerably rich.

- When studying synanthropic environments more attention should be devoted to their diversity. Big differences in species composition, numbers and dominance structure were observed between indoor spaces and outdoor walls.

- Exposition (insolation) and the presence of trees had a great influence on species composition of spiders inhabiting building walls.

- Achaearanea tabulata, sporadically recorded from Europe so far, was a common species and permanently established itself in synanthropic environments.

- Partial replacement of Achaearanea tepidariorum by more expansive A. tabulata from synanthropic environments was observed.

- Numerous occurrences of spiders inhabiting bark were found on outer walls. It can show high adaptative abilities as well as it may be treated as the initial stage of synanthropisation.

\section{REFERENCES}

BAIRD C.R. \& AKRE R. D. 1993. Range extension of the aggressive house spider Tegenaria agrestis into southern Idaho, Utah, and Montana. Proceedings of the Washington State Entomological Society 55: 996-1000.

BAiRD C. R. \& STOLTZ R. L. 2002. Range expansion of the hobo spider, Tegenaria agrestis, in the northwestern United States. Journ. Arachnol. 30: 201-204.

BorowieC B. 1999. Psilochorus simoni (Aranei, Pholcidae), a new spider species for Wrocław. Przegl. Zool., Wrocław, 43: 187-188. [In Polish]

Czajka M. 1966. Spiders (Araneae) of the Massif of Ślęża. [In Polish] Acta Univ. Wratisl. Zool., Wrocław, 2: 71-124.

Dimitrov D. 1994. A record of Achaearanea tabulata from the Balkan Peninsula (Araneae: Theridiidae). Arachnol. Mitt. 8: 77-79.

DZIABASZEWSKi A. 1983. Dalsze spostrzeżenia nad fauną pająków (Aranei) miast na przykładzie Warszawy, Poznania i Kołobrzegu, p. 44-45. XIII Zjazd Polskiego Towarzystwa Zoologicznego, Katowice, 176 pp. [Abstract book]

DziabaszewSKI A. 1987. Pająki (Aranei) zabudowań Poznania, p. 57. XIV Zjazd Polskiego Towarzystwa Zoologicznego, Szczecin, 262 pp. [Abstract book]

DZIABASZEWSKI A. 1989. Faunistic remarks about rare species of spiders (Aranei) from Poznan (with list of 302 recorded species). [In Polish]. Badania fizjograficzne nad Polską Zachodnią, C, Poznań, 38: 5-21. 
DZIABASZEWSKI A. 1990. Pająki (Aranei) Roztocza Środkowego, p. 28.. In: Materiały z sympozjum „Fauna Roztocza - zasoby, przemiany, ochrona. Zwierzyniec, 25-27.09.1990”. Instytut Zoologii PAN, Warszawa, 53 pp.

DZIABASZEWSKi A. 1991a. Spider (Aranei) species of Malbork Castle and other selected buildings in Elbląg Province. Prace Komisji Biologicznej, Towarzystwo Przyjaciół Nauk, Poznań, 73: 5-18. [In Polish]

Dziabaszewski A. 1991b. Spiders (Aranei) new for Poznań. [In Polish]. Prace Komisji Biologicznej, Towarzystwo Przyjaciół Nauk, Poznań, 73: 27-34.

Dziabaszewski A. 1995. Spiders (Aranei) of buildings in the city of Poznań. Badania fizjograficzne nad Polską. Zachodnią, C, Poznań, 42: 7-38. [In Polish].

DziabaszewsKi A. 2002. Loty na nici pajęczej, pp. 134-144. In: Kronika miasta Poznania 2002/3: Wśród zwierząt i roślin, Wydawnictwo Miejskie, Poznań.

Gromov A.V. 1997. New records of spider Achaearanea tabulata Levi (Arachnida, Araneae, Theridiidae) in Palearctics. Izvestiya Ministerstva Nauki Akademii Nauk Respubliki Kazakhstan, 1 (199): 31-35.

HeINZ M., NÄHRIG D. \& STORCH V. 2003. Synanthrope Spinnen (Araneae) in Nordbaden. Carolinea 60: 141-150.

JANKOWSKI A. 1989. The spiders of the buildings in Opalenica and Grodzisk Wielkopolski. Badania fizjograficzne nad Polską Zachodnią, C, Poznań, 38: 23-34. [In Polish]

Klein W., Stock M. \& Wunderlich J. 1995. Zwei nach Deutschland eingeschleppte Spinnenarten (Araneae) Uloborus plumipes Lucas und Eperigone eschatologica (Bishop) - als Gegenspieler der Weissen Fliege im Geschützten Zierpflanzenbau? Beitr. Araneol. 4. 301-306.

KNOFlach B. 1991. Achaearanea tabulata Levi, eine für Österreich neue Kugelspinne (Arachnida, Aranei: Theridiidae). Ber. naturw.-med. Ver., Innsbruck, 78: 59-64.

KrZyŻanowska E., DZiabaszewSki A., Jackowska B. \& StaręGa W. 1981. Spiders (Arachnoidea, Aranei) of Warsaw and Mazovia. Memorabilia zool., 34: 87-110.

LeVI H. W. 1980. Two species of the genera Theridion and Achaearanea from North America (Araneae: Theridiidae). Trans. Amer. Micros. Soc. 99: 334-337.

Moritz M., LeVi H.W. \& Pfüller R. 1988. Achaearanea tabulata Levi, eine für Mitteleuropa neue Kugelspinne (Araneae, Theridiidae). Deuts. Ent. Zeits. 35. 361-367.

PlatNick N. I. 2006. The world spider catalog, version 6.5. American Museum of Natural History, online at http://research.amnh.org/entomology/spiders/catalog/index.html

POVOLNY D. 1963. Einige Erwägungen über die Beziehungen zwischen den Begriffen "Synanthrop" und "Kulturfolger". Beitr. Entomol. 13: 439-444.

PRÓSZYŃSKi J. \& STARĘGA W. 1971. Pająki - Aranei. Katalog Fauny Polski 33. PWN, Warszawa, 382 pp.

PUSZKAR T. 1981. New Species of Spiders (Aranei) in the Lublin Upland. Annales UMCS, sec. C, 36: 273-287. [In Polish]

RozWAŁKA R. 1996. Materials for an Understanding of Spiders of Poleski National Park and the Surronding Area. Parki Narodowe i Rezerwaty Przyrody, Białowieża, 15: 63-73. [In Polish].

RozWAŁKA R. 2000. Spiders (Araneae) of the Brachypodio-Teucrietum association in the Stawska Góra reserve. In: Łętowski J (ed.), Walory przyrodnicze Chełmskiego Parku Krajobrazowego i jego najbliższych okolic, pp. 109118. UMCS, Lublin. [In Polish]

RozWAlKA R. 2004. A contribution to the knowledge of spiders (Araneae) of Roztocze., Nowy Pamiętnik Fizjograficzny 3 (1-2): 101-116. [In Polish]

SACHER P. 1983a. Spinnen (Araneae) an und in Gebäuden - Versuch eine Analyse der synanthropen Spinnenfauna in der DDR. Teil I. Ent. Nachr. Ber. 27: 97-104.

SACHER P. 1983b. Spinnen (Araneae) an und in Gebäuden - Versuch eine Analyse der synanthropen Spinnenfauna in der DDR. Teil II. Ent. Nachr. Ber. 27: 141-152.

SACHER P. 1983c. Spinnen (Araneae) an und in Gebäuden - Versuch eine Analyse der synanthropen Spinnenfauna in der DDR. Teil III. Ent. Nachr. Ber. 27: 197-204, 224.

SCHMIDT G. \& Krause R.H. 1996. «Haus» spinnen. Unterricht Biologie 20: 32-38.

SIMON U. 1997. On the biology of Dipoena torva (Araneae: Theridiidae). Arachnol. Mitt. 13: 29-40.

STARĘGA W. 1983. Kritisches Verzeichnis der Spinnen (Aranei) Polen. Fragm. Faun. 27: 149-268. [In Polish]

STARĘGA W. 1984. Materialien zur Kenntnis der Verbreitung der Spinnen (Aranei) in Polen, VIII-X. Fragm. Faun. 28 : 79-136. [In Polish]

StaręGA W. 1988. Spinnen (Aranei) des Lysa Gora-Gebirges. Fragm. Faun., 31: 185-359. [In Polish].

STARĘGA W. 1996. Spinnen (Araneae) von oberschlesischen Abraumhalden des Steinkohlebergbaus. Fragm. Faun. 39 : $329-344$.

STARĘGA W. 2000. Spinnen aus Roztocze und anliegenden Gebieten. Fragm. Faun. 43: 59-89.

StARĘGA W. 2003. Spiders (Araneae) of the Knyszyn Forest. Nowy Pamiętnik Fizjograficzny 1: 95-206. [In Polish]

STARĘGA W. 2004. Check-list of Polish spiders. http://www.arachnologia.edu.pl/wykazpaj.html

STERZYŃSKA M. \& ŚLEPOWROŃSKI A. 1994. Spiders (Aranei) of tree canopies in Polish pine forests. Fragm. Faun. 36: $485-500$.

VALESOVA-ZDARKOVA E. 1966. Synanthrope Spinnen in der Tschechoslowakei (Arach., Araneae). Senckenbergiana biol. 47: 73-75. 
VANUYTVEN H. 1987. Een eerste poging tot de indeling van oonze "huisspinnen" in eusynanthrope en hemisynanthrope soorten. Nwsbr. Belg. Arachnol. Ver. 5: 6-7.

ŻABKA M. 1997. Salticidae - Pająki skaczące (Arachnida: Araneae). Fauna Polski, 19. Muzeum i Instytut Zoologii, Warszawa, $189 \mathrm{pp}$.

\section{STRESZCZENIE}

[Pająki (Araneae) wybranych środowisk synantropijnych Lublina]

Celem pracy było poznanie zgrupowań pająków (Araneae) wybranych środowisk synantropijnych Lublina. Pająki zbierano w pomieszczeniach mieszkalnych, szklarniach, na ścianach zewnętrznych o różnej ekspozycji słonecznej oraz na betonowych (asfaltowych) placach i ulicach. Zebrany materiał liczył 1496 okazów, wśród których stwierdzono 97 gatunków pająków. W zależności od stopnia przywiązania do środowisk synantropijnych, zebrane gatunki pająków podzielono na trzy grupy ekologiczne: eusynantropy, hemisynantropy i asynantropy. Stwierdzono duże różnice w składzie gatunkowym i liczebności zgrupowań pająków w zależności od wyróżnionego „rodzaju środowiska synantropijnego”. Różnice w składzie gatunkowym były również widoczne na poziomie wyróżnionych grup ekologicznych. Wśród wykazanych gatunków były obecne pająki rzadko spotykane w Polsce Dipoena torva i Leptorchestes berolinensis. Jednocześnie stwierdzono, że Achaearanea tabulata - gatunek, który przybył w latach 80-tych do Europy, jest stałym i pospolitym elementem arachnofauny Polski. 